\title{
Agro-Morphological Traits And Root Yield Of An Improved Cassava (Manihot Esculenta Crantz) Variety Under Nutrient-Applied Conditions In Offinso Municipality Of Ghana
}

\author{
K. G. Santo, A. Muntala, and P. M. Norshie
}

\begin{abstract}
Field studies were undertaken at Offinso in the Ashanti Region of Ghana during the 2015/2016 growing season to evaluate growth, root and dry matter yields of an improved cassava variety (Bankyehemaa) treated with poultry manure (PM), NPK 15-15-15 and NPK 23-10-10 fertilizers. The treatment structure was a $3 \times 4$ factorial, laid out in a Randomized Complete Block Design with three replications. Three levels of fertilizer $(600 \mathrm{~kg} / \mathrm{ha}$ NPK $15-15-15,600 \mathrm{~kg} / \mathrm{ha}$ NPK 23-10-10 and 2 t/ha PM) were applied at $6,8,10$ and 12 weeks after planting. The parameters measured included plant height, fresh and dry shoot weights, number of stems per plant, stem girth, fresh and dry root yields and total dry matter yield. The data collected were subjected to analysis of variance using the Genstat Statistical package. Main effects of fertilizer type and time of fertilizer application on most of the parameters measured were not significant. However, the interaction effects of the two factors were significant in all the parameters measured. Vegetative growth of Bankyehemaa increased when mineral fertilizers were applied earlier than 12 weeks after planting. The highest fresh and dry shoot weights and the biggest stems were produced when NPK 15-15-15 fertilizer was applied at 6 weeks after planting. Plants treated with NPK 1515-15 fertilizer at 10 weeks after planting were the tallest, while those treated with NPK 23-10-10 fertilizer at 8 weeks after planting produced the highest number of stems per plant. Application of poultry manure at 6 weeks after planting produced the highest fresh cassava root yield of $28.10 \mathrm{t} / \mathrm{ha}$. The highest dry matter yield of $19.80 \mathrm{t} / \mathrm{ha}$ was obtained when poultry manure was applied at 12 weeks after planting.

Index Terms - agromorphological traits, application time, cassava, nutrient-applied conditions, root yield
\end{abstract}

\section{INTRODUCTION}

Cassava (Manihot esculenta Crantz) originated in Latin America and was introduced into Africa by the Portuguese in the $16^{\text {th }}$ century [1]. The storage roots are the main products of importance. [2] reported that a wild form of Manihot which was genetically identical to cultivated species was found in Goias in Central Brazil. [3] and [4] reported that the modern cultivated cassava is a descendant of the subspecies of the wild form called Manihot esculenta subsp. Flabellifolia.

[5] reported that both cassava and yam contribute about $46 \%$ of agricultural Gross Domestic Product (GDP) in

Ghana. [5] subsequently reported that cassava is cultivated

Published on May 21, 2020

K. G Santo, Department of Horticulture and Crop Production, School of Agriculture and Technology, University of Energy and Natural Resources, Ghana. (e-mail: kwadwogyasisanto@yahoo.com)

A. Muntala, Department of Horticulture and Crop Production, School of Agriculture and Technology, University of Energy and Natural Resources, Ghana. (e-mail: muntala.abdulai@uenr.edu.gh) in every part of the country by nearly every farmer and that the daily calorie intake of cassava is $30 \%$ in Ghana. According to [6], fresh root yield of cassava increased more than $40 \mathrm{t} / \mathrm{ha}$ when higher rates of NPK fertilizers were applied. [7] observed an average cassava fresh root yield of $23.7 \mathrm{t} / \mathrm{ha}$ with application of $4 \mathrm{t} / \mathrm{ha}$ poultry manure.

According to [8], cassava has the potential to bridge the food gap in Africa, but yields are generally low partly because of the low fertility status of the soils on which cassava is grown. Work done by [9] showed that the root yield of cassava in Ghana is low, ranging between 5.0 and $11.8 \mathrm{t} / \mathrm{ha}$, although cassava has the yield potential of up to $30 \mathrm{t} / \mathrm{ha}$. It reported that this low yield could be due to diseases and pests and the low soil fertility status of most of the soils on which cassava is grown. [10] reported that the low soil fertility has been accelerated by nutrient mining from the soil during crop harvest, erosion and leaching and failure of farmers to add soil amendments through crop residues, organic manures and mineral fertilizers.

The main objective was, therefore, to evaluate the effect of poultry manure and two different NPK fertilizers on productivity of an improved cassava variety. The specific objective of this research was to determine the effect of poultry manure, NPK 15-15-15 and NPK 23-10-10 fertilizers, and their time of application on growth, root and dry matter yields of Bankyehemaa.

\section{MATERIALS AND METHODS}

\section{A. Experimental site}

The research was undertaken at Namong Senior High Technical School in the Offinso Municipality in the Ashanti Region of Ghana (6’45 N and 7’25 N, $1^{\circ} 65 \mathrm{~W}$ and $1^{\circ} 45 \mathrm{E}$ with an elevation of $250 \mathrm{~m}-300 \mathrm{~m}$ above sea level) from June, 2015 to May, 2016. The area is located in the moist semi deciduous forest agro-ecological zone [11], and has double maxima rainfall pattern. The major season rains begin from mid-March to the end of July with a peak fall in June. The minor season rains start in September and end in mid November with a peak fall in October. A period of dry conditions from December to March separates the major

P. M. Norshie, Department of Horticulture and Crop Production, School of Agriculture and Technology, University of Energy and Natural Resources, Ghana. (e-mail: norshie@yahoo.com). 
season and minor season rains. Annual rainfall ranges from $1500 \mathrm{~mm}$ to $1700 \mathrm{~mm}$. The major rainy season is associated with humid conditions. A maximum temperature of $30^{\circ} \mathrm{C}$ is experienced between March and April, and near monthly temperature is about $27^{\circ} \mathrm{C}$. The soil is moderately shallow, red, well drained, light clay and belongs to the Kumasi series (Ochrosols or Ferric Acrisol). Tables 1 and 2 show the physico-chemical characteristics of the soil at the experimental site. Rainfall and temperature figures at the experimental site during the growth period are presented in Table 3.

Table 1: Soil chemical properties of study site

\begin{tabular}{|c|c|c|c|}
\hline \multicolumn{2}{|c|}{ Chemical property } & \multicolumn{2}{|l|}{ Level } \\
\hline \multicolumn{2}{|l|}{$\mathrm{pH}$} & \multicolumn{2}{|l|}{6.11} \\
\hline \multicolumn{2}{|c|}{ Organic carbon $(\%)$} & \multicolumn{2}{|l|}{1.24} \\
\hline \multicolumn{2}{|c|}{ Organic matter $(\%)$} & \multicolumn{2}{|l|}{2.13} \\
\hline \multicolumn{2}{|c|}{ Nitrogen $(\%)$} & \multicolumn{2}{|l|}{0.07} \\
\hline \multicolumn{2}{|c|}{ Phosphorus (ppm) } & \multicolumn{2}{|l|}{7.80} \\
\hline \multicolumn{4}{|c|}{ Exchangeable cations $(\mathrm{Cmol} / \mathrm{kg})$} \\
\hline \multicolumn{2}{|c|}{ Potassium } & \multicolumn{2}{|l|}{0.00} \\
\hline \multicolumn{2}{|l|}{ Calcium } & \multicolumn{2}{|l|}{5.98} \\
\hline \multicolumn{2}{|l|}{ Magnesium } & \multicolumn{2}{|l|}{0.64} \\
\hline \multicolumn{2}{|l|}{ Sodium } & \multicolumn{2}{|l|}{0.16} \\
\hline \multicolumn{2}{|c|}{ EXC Acidity $(\mathrm{Al}+\mathrm{H})$} & \multicolumn{2}{|l|}{3.17} \\
\hline \multirow{2}{*}{\multicolumn{4}{|c|}{$\frac{\mathrm{CEC}(\mathrm{Cmol} / \mathrm{kg} / \mathrm{Me} / 100 \mathrm{~g})}{\text { KNUST Soil Science Laboratory (2015) }}$}} \\
\hline & & & \\
\hline \multicolumn{4}{|c|}{ Table 2: Soil physical properties of study site } \\
\hline \multicolumn{2}{|c|}{ Soil separates $(\%)$} & \multicolumn{2}{|c|}{ \% Composition } \\
\hline \multicolumn{4}{|c|}{$\begin{array}{ll}\text { Sand } & 71.78\end{array}$} \\
\hline Silt & & & \\
\hline Clay & & & \\
\hline Texture & & y loam & \\
\hline KNUST Soil Sc & Laboratory $(20$ & & \\
\hline Table 3: Rainfall & $\begin{array}{l}\text { mperature figu } \\
015 / 2016 \text { grow }\end{array}$ & $\begin{array}{l}\text { ee experimen } \\
\text { son }\end{array}$ & te during \\
\hline Month & $\begin{array}{l}\text { Rainfall } \\
(\mathrm{mm})\end{array}$ & $\begin{array}{l}\text { Temp } \\
\left({ }^{\circ} \mathrm{C}\right)\end{array}$ & ure \\
\hline & & Max. & Min. \\
\hline June & 206.5 & 30.4 & 21.4 \\
\hline July & 103.7 & 29.0 & 21.3 \\
\hline August & 10.2 & 28.5 & 21.7 \\
\hline September & 56.7 & 30.0 & 20.9 \\
\hline October & 163.6 & 31.8 & 21.8 \\
\hline November & 21.6 & 32.1 & 22.1 \\
\hline December & 0.0 & 33.2 & 20.5 \\
\hline January & 0.0 & 34.2 & 18.4 \\
\hline February & 6.3 & 35.8 & 21.1 \\
\hline March & 92.9 & 34.8 & 23.0 \\
\hline April & 105.9 & 34.3 & 23.3 \\
\hline May & 92.0 & 32.9 & 23.2 \\
\hline & $\begin{array}{l}\text { Total } \\
859.4\end{array}$ & & \\
\hline
\end{tabular}

KNUST Animal Science Meteorological Station (2015/2016)

\section{B. Experimental Design and Treatments}

The treatment structure was a 3 x 4 factorial, arranged in a Randomized Complete Block Design with three replications, giving a total of 12 treatment combinations. Bankyehemaa was grown with two mineral fertilizers and poultry manure as levels of one factor as follows:

- $\quad$ NPK 15:15:15 at $600 \mathrm{~kg} / \mathrm{ha} \quad\left(90 \mathrm{~kg} \mathrm{~N} \mathrm{ha}^{-1} ; 90 \mathrm{~kg}\right.$ $\mathrm{P}_{2} \mathrm{O}_{5} \mathrm{ha}^{-1}$; $90 \mathrm{~kg} \mathrm{~K}_{2} \mathrm{O}$ ha $^{-1}$ );

- $\quad$ NPK 23:10:10 at $600 \mathrm{~kg} / \mathrm{ha}\left(138 \mathrm{~kg} \mathrm{~N} \mathrm{ha}^{-1} ; 60 \mathrm{~kg}\right.$ $\mathrm{P}_{2} \mathrm{O}_{5}$ ha $^{-1} ; 60 \mathrm{~kg} \mathrm{~K}_{2} \mathrm{O}$ ha $^{-1}$ );

- Poultry Manure at $2 \mathrm{t} / \mathrm{ha}$.

The time of application of fertilizer was the other factor with four levels, namely:

- Application of fertilizer 6 weeks after planting;

- Application of fertilizer 8 weeks after planting;

- Application of fertilizer 10 weeks after planting; Application of fertilizer 12 weeks after planting.

\section{Agronomic Practices}

The land was cleared with a cutlass and the regrowths were chemically controlled two weeks after slashing with a systemic herbicide (glyphosate), called 'sunphosate' at the rate of $10 \mathrm{ml}$ per litre of water. The field was then prepared into plots each measuring $4.0 \mathrm{~m}$ (intra-row) x $8.0 \mathrm{~m}$ (interrow) with $1 \mathrm{~m}$ between plots and $1 \mathrm{~m}$ between blocks. Cassava planting materials were obtained from the cassava multiplication unit of the Ministry of Food and Agriculture, Asante Mampong. The planting materials consisted of mature stem cuttings (stakes) of about $20 \mathrm{~cm}$ in length, containing between 10 and 12 nodes. These were planted in an angled position at a spacing of $1 \mathrm{~m} \mathrm{x} 1 \mathrm{~m}$ on flat-tilled land on $18^{\text {th }}$ June, 2015 to give a plant population of 10,000 plants per hectare. Each plot consisted of 32 plants. Replanting was done at 2-3 weeks after planting depending on the availability of soil moisture.

Fertilizer was applied as per the treatments imposed. Plots with NPK 15-15-15 and NPK 23-10-10 treatments were fertilized (side banded) at the rate of $600 \mathrm{~kg} / \mathrm{ha}$ for each of the treatments and plots with poultry manure were fertilized at the rate of $2 \mathrm{t} / \mathrm{ha}$ at $6,8,10$ and 10 weeks after planting. Rodents and termites were serious pests during the experiment and scare-crows were used to ward away the rodents. The termites were controlled with K-othrine at the rate of $192.9 \mathrm{~kg} / \mathrm{ha}$ by broadcasting. Weeds were controlled by hoeing as and when necessary during the first two months of growth until canopy closure. Harvesting of cassava storage roots was undertaken at 11 months after planting.

\section{Data Collected}

Plant height was measured at three, five and seven months after planting. Four plants from the centre row of each plot were selected and tagged. The height of each of the plants was measured with a graduated pole from the ground level to the tip of the tallest leaf (terminal end of the plant). The mean plant height was then recorded. Four plants were randomly harvested from each treatment and the mean fresh shoot weight was taken. The samples were oven-dried to constant weights, and their dry weights were taken. The diameter of the stems per plant was taken with vernier calipers and the average was calculated. Four plants were selected from each treatment and the number of stems was counted. The mean number of stems was then calculated. Four plants from an area covering $4 \mathrm{~m}^{2}$ were harvested per treatment and the fresh root weight measured and then converted to kilograms $(\mathrm{kg})$ 
per hectare and then to tonnes per hectare as follows. Fresh root yield ( $\mathrm{t} / \mathrm{ha}$ ) was computed by dividing the weight of roots harvested in $\mathrm{kg}$ by the number of plants harvested per area and multiplied by 10,000. The fresh root yield was oven-dried to a constant weight and the dry root weight was measured. The total dry shoot weight was added to the total dry root weight to obtain the total dry matter yield.

\section{E. Data Analysis}

The data were exposed to ANOVA using the Genstat Statistical package [12]. Two-way ANOVA was applied to test for the variations among the fertilizer treatments applied at different times. The LSD at probability level of 5\% was used to compare treatment means.

\section{RESULTS}

\section{A. Plant height}

Results of plant height are presented in Table 4. The results showed that plant height did not vary among various treatments on all sampling days. However, there was significant $(\mathrm{P}<0.05)$ interaction between fertilizer and its time of application for plant height at all the sampling periods. At harvest, the highest interaction effect $(208.70 \mathrm{~cm})$ was observed when cassava plants were treated with NPK 15-1515 at 10 weeks after planting, whereas the lowest interaction effect $(183.10 \mathrm{~cm})$ was noticed when poultry manure was applied at 10 weeks after planting.

Table 4: Plant height at different harvesting periods for cassava under three fertilizer types applied at four different times in 2015/2016 growing season

\begin{tabular}{|c|c|c|c|c|c|c|c|c|c|}
\hline \multirow[t]{4}{*}{ Treatment } & \multicolumn{9}{|c|}{ Plant height $(\mathrm{cm})$} \\
\hline & \multicolumn{9}{|c|}{ Months After Planting } \\
\hline & \multicolumn{3}{|c|}{3} & \multicolumn{3}{|c|}{5} & \multicolumn{3}{|c|}{7} \\
\hline & F1 & F2 & F3 & F1 & F2 & F3 & F1 & F2 & F3 \\
\hline $6 \mathrm{WAP}$ & 41.70 & 57.20 & 48.30 & 178.70 & 175.30 & 182.35 & 192.10 & 195.20 & 186.70 \\
\hline $8 \mathrm{WAP}$ & 67.40 & 59.90 & 60.50 & 173.87 & 187.95 & 181.53 & 200.20 & 200.20 & 199.20 \\
\hline 10 WAP & 46.70 & 44.30 & 55.10 & 176.47 & 186.38 & 179.60 & 208.70 & 194.30 & 183.10 \\
\hline 12 WAP & 49.90 & 46.50 & 56.80 & 178.10 & 175.40 & 178.63 & 199.40 & 195.70 & 187.00 \\
\hline NPK 15-15-15 (F1) & & 50.90 & & & 176.78 & & & 200.10 & \\
\hline NPK $23-10-10$ (F2) & & 52.00 & & & 181.26 & & & 196.40 & \\
\hline Poultry manure (F3) & & 55.20 & & & 180.53 & & & 189.00 & \\
\hline 6 WAP & & 49.10 & & & 178.78 & & & 191.30 & \\
\hline $8 \mathrm{WAP}$ & & 62.60 & & & 181.12 & & & 199.90 & \\
\hline 10 WAP & & 48.70 & & & 180.82 & & & 195.40 & \\
\hline 12 WAP & & 50.40 & & & 177.38 & & & 194.00 & \\
\hline \multicolumn{10}{|l|}{$\operatorname{LSD}(\mathrm{P}=0.05)$} \\
\hline Fertilizer $(\mathrm{F})$ & & NS & & & NS & & & NS & \\
\hline Time (T) & & NS & & & NS & & & NS & \\
\hline $\mathrm{F} \times \mathrm{T}$ & & 24.62 & & & 9.36 & & & 22.97 & \\
\hline CV (\%) & & 27.60 & & & 3.10 & & & 7.00 & \\
\hline
\end{tabular}

NS: Not Significant WAP: weeks after planting

\section{B. Fresh and Dry Shoot weights}

Results of fresh and dry shoot weights as presented in Table 5 showed that application of fertilizer and its time of application did not significantly $(\mathrm{P}>0.05)$ influence the two parameters. However, the interaction effect between the two factors for fresh and dry shoot weights was significant $(\mathrm{P}<0.05)$. The highest interaction effects for fresh shoot weight and dry shoot weight were $4.76 \mathrm{~kg} /$ plant and 1.19 $\mathrm{kg} /$ plant, respectively following application of NPK 15-15-15 at 6 weeks after planting. The lowest interaction effect for fresh shoot weight ( $2.56 \mathrm{~kg} /$ plant) and dry shoot weight ( 0.59 $\mathrm{kg} /$ plant) was associated with application of NPK 23-10-10 at 12 weeks after planting.

Table 5: Fresh and dry shoot weights for cassava at harvest under three fertilizer types applied at four different times in 2015/2016 growing season

\begin{tabular}{|c|c|c|c|c|c|c|}
\hline \multirow[t]{2}{*}{ Treatment } & \multicolumn{3}{|c|}{ Fresh shoot weight (kg/plant) } & \multicolumn{3}{|c|}{ Dry shoot weight (kg/plant) } \\
\hline & F1 & $\mathrm{F} 2$ & F3 & F1 & & F3 \\
\hline $6 \mathrm{WAP}$ & 4.76 & 3.51 & 3.57 & 1.19 & 0.88 & 0.82 \\
\hline 8 WAP & 4.20 & 3.72 & 3.41 & 1.05 & 0.93 & 0.79 \\
\hline 10 WAP & 3.28 & 3.37 & 3.57 & 0.79 & 0.78 & 0.83 \\
\hline 12 WAP & 3.06 & 2.56 & 4.16 & 0.77 & 0.59 & 0.97 \\
\hline NPK 15-15-15 (F1) & & 3.80 & & & 0.95 & \\
\hline NPK 23-10-10 (F2) & & 3.29 & & & 0.80 & \\
\hline Poultry manure (F3) & & 3.68 & & & 0.85 & \\
\hline $6 \mathrm{WAP}$ & & 3.95 & & & 0.97 & \\
\hline $8 \mathrm{WAP}$ & & 3.77 & & & 0.92 & \\
\hline 10 WAP & & 3.41 & & & 0.80 & \\
\hline 12 WAP & & 3.26 & & & 0.78 & \\
\hline \multicolumn{7}{|l|}{$\operatorname{LSD}(\mathrm{P}=0.05)$} \\
\hline Fertilizer types $(F)$ & & NS & & & NS & \\
\hline Time of application (T) & & NS & & & NS & \\
\hline $\mathrm{F} \times \mathrm{T}$ & & 1.65 & & & 0.41 & \\
\hline $\mathrm{CV}$ & & 27.00 & & & 27.90 & \\
\hline
\end{tabular}

\section{Number of stems per plant and mean stem girth}

Results of number of stems per plant and mean stem girth are presented in Table 6 . The results showed that the number of stems per plant was not significantly $(\mathrm{P}>0.05)$ affected by the fertilizer-applied treatments and time of fertilizer application. Application of fertilizer did not significantly ( $\mathrm{P}>0.05$ ) influence stem girth, but time of application did. Application of fertilizer at 6 weeks after planting produced the greatest treatment effect, and this was significantly $(\mathrm{P}<0.05)$ higher than application of fertilizer at 10 weeks after planting only, which recorded the lowest treatment mean. All other treatment differences were not significant. There was significant $(\mathrm{P}<0.05)$ interaction between fertilizer and its time of application. For number of stems per plant, the best interaction effect (2.08) was shown in NPK 23-10-10 applied at 8 weeks after planting, while the worst (1.25) was noticed in NPK 15-15-15 and poultry manure applied at 6 weeks after planting and 12 weeks after planting, respectively. Application of NPK 15-15-15 at 6 weeks after planting had the greatest interaction effect $(29.31 \mathrm{~mm})$ for stem girth, but the least interaction effect of $22.76 \mathrm{~mm}$ was obtained when plants were treated with poultry manure at 10 weeks after planting.

\section{Table 6: Number of stems per plant and stem girth at harvest for cassava under three fertilizer types applied at four different times in 2015/2016 growing season}

\begin{tabular}{|c|c|c|c|c|c|c|}
\hline \multirow[t]{2}{*}{ Treatment } & \multicolumn{3}{|c|}{ Number of stems per plant } & \multicolumn{3}{|c|}{ Stem girth $(\mathrm{mm})$} \\
\hline & F1 & F2 & F3 & F1 & $\mathrm{F} 2$ & F3 \\
\hline 6 WAP & 1.25 & 1.67 & 1.50 & 29.31 & 26.77 & 25.76 \\
\hline $8 \mathrm{WAP}$ & 1.83 & 2.08 & 1.33 & 24.42 & 24.47 & 28.87 \\
\hline 10 WAP & 2.00 & 1.50 & 2.00 & 24.36 & 25.71 & 22.76 \\
\hline $12 \mathrm{WAP}$ & 2.00 & 1.75 & 1.25 & 25.04 & 23.85 & 27.90 \\
\hline NPK $15-15-15$ (F1) & & 1.77 & & & 25.78 & \\
\hline NPK $23-10-10$ (F2) & & 1.75 & & & 25.20 & \\
\hline Poultry manure (F3) & & 1.52 & & & 26.30 & \\
\hline 6 WAP & & 1.47 & & & 27.28 & \\
\hline 8 WAP & & 1.75 & & & 25.92 & \\
\hline $10 \mathrm{WAP}$ & & 1.83 & & & 24.28 & \\
\hline $12 \mathrm{WAP}$ & & 1.67 & & & 25.60 & \\
\hline \multicolumn{7}{|l|}{$\operatorname{LSD}(\mathrm{P}=0.05)$} \\
\hline Fertilizer types (F) & & NS & & & NS & \\
\hline Time of application (T) & & NS & & & 2.47 & \\
\hline $\mathrm{F} \times \mathrm{T}$ & & 0.69 & & & 4.27 & \\
\hline $\mathrm{CV}$ & & 24.20 & & & 9.80 & \\
\hline
\end{tabular}

NS: Not Significant WAP: weeks after planting

\section{Fresh root yield, dry root yield and total dry matter yield}

Results of fresh, dry root and total dry matter yields are presented in Table 7. Fresh, dry root and total dry matter yields of cassava were not significantly $(\mathrm{P}>0.05)$ affected by 
application of fertilizer. However, time of fertilizer application affected dry root yield significantly. Application of fertilizer at 6 weeks after planting produced significantly greater dry root yield than application at 10 weeks after planting only. All other treatment effects were similar. There was significant $(\mathrm{P}<0.05)$ interaction between fertilizer and its time of application. Application of poultry manure at 6 weeks after planting recorded the greatest interaction effect $(28.10$ t/ha and $11.23 \mathrm{t} / \mathrm{ha}$ ) for fresh root yield and dry root yield, respectively, while the least interaction effect of for fresh root yield $(15.25 \mathrm{t} / \mathrm{ha})$ and dry root yield $(5.53 \mathrm{t} / \mathrm{ha})$ was obtained when plants were treated with poultry manure at 10 weeks after planting. The highest (19.80 t/ha) and lowest (13.83 $\mathrm{t} / \mathrm{ha}$ ) interaction effects for total dry matter yield were produced by application of poultry manure at 12 weeks after planting and 10 weeks after planting, respectively.

Table 7: Fresh, dry root and total dry matter yields for cassava at harvest under three fertilizer types applied at four different times in 2015/2016 growing season

\begin{tabular}{|c|c|c|c|c|c|c|c|c|c|}
\hline \multirow[t]{3}{*}{ Treatment } & \multirow{2}{*}{\multicolumn{3}{|c|}{ Fresh root yield (tha) }} & \multirow{2}{*}{\multicolumn{3}{|c|}{ Dry root vield (tha) }} & \multirow{2}{*}{\multicolumn{3}{|c|}{ Total dry matter vield (tha) }} \\
\hline & & & & & & & & & \\
\hline & F1 & F2 & $F^{3}$ & F1 & F2 & F3 & $\mathrm{F} 1$ & F2 & F3 \\
\hline 6 WAP & 19.13 & 22.31 & 28.10 & 7.10 & 8.23 & 11.23 & 19.47 & 17.07 & 18.30 \\
\hline 8 WAP & 20.52 & 23.23 & 24.86 & 8.23 & 9.28 & 8.07 & 18.73 & 16.97 & 17.80 \\
\hline $10 \mathrm{WAP}$ & 19.29 & 23.23 & 15.25 & 6.53 & 8.53 & 5.53 & 14.87 & 17.07 & 13.83 \\
\hline 12 WAP & 26.18 & 17.04 & 25.13 & 9.57 & 6.83 & 9.17 & 16.53 & 11.63 & 19.80 \\
\hline NPK 15-15-15 (F1) & & 21.28 & & & 786 & & & 17,40 & \\
\hline NPK $23-10-10$ (F2) & & 21.45 & & & 8.22 & & & 15.68 & \\
\hline Poultry manure $(\mathrm{F} 3)$ & & 23.34 & & & 8.50 & & & 17.43 & \\
\hline 6 WAP & & 23.18 & & & 8.86 & & & 18.28 & \\
\hline 8 WAP & & 22.87 & & & 8.53 & & & 17.83 & \\
\hline $10 \mathrm{WAP}$ & & 19.26 & & & 6.87 & & & 15.26 & \\
\hline 12 WAP & & 22.78 & & & 8.52 & & & 15.26 & \\
\hline \multicolumn{10}{|l|}{$\operatorname{LSD}(\mathrm{P}=0.05)$} \\
\hline Fertilizer $(\mathrm{F})$ & & NS & & & NS & & & NS & \\
\hline Time (T) & & NS & & & 1.87 & & & NS & \\
\hline $\mathrm{F} \times \mathrm{T}$ & & 8.09 & & & 3.24 & & & 5.86 & \\
\hline CV (\%) & & 21.70 & & & 23.40 & & & 20.60 & \\
\hline
\end{tabular}

NS: Not Significant

WAP: weeks after planting

\section{DISCUSSION}

\section{A. Treatment effects on vegetative growth of cassava}

Growth in cassava was measured as plant height, shoot weight per plant, number of stems per hill and stem girth. Results of vegetative growth as presented in Tables 4, 5 and 6 showed no significant differences due to the application of fertilizer on all the days of sampling. Time of fertilizer application did not affect vegetative growth, except stem girth which was significantly maximized when fertilizer was applied at 6 weeks after planting. This supports findings of [13] who reported that plant height was not significantly affected when the time of fertilizer application was varied at 8, 16 and 24 weeks after planting. [14] also reported no significant differences between single application at 30 days after planting and split application at 30 and 60 days after planting or at 30,60 and 90 days after planting.

There was significant $(\mathrm{P}<0.05)$ interaction between fertilizer and its time of application for plant height at all the sampling periods. At harvest, results of interaction effect for plant height showed that the tallest plants were produced following the application of NPK 15-15-15 at 10 weeks after planting. The highest interaction effect for fresh shoot weight, dry shoot weight and stem girth was recorded when NPK 1515-15 was applied at 6 weeks after planting. For number of stems per plant, the best interaction effect was shown in NPK 23-10-10 applied at 8 weeks after planting. Generally, results of the interaction effect between fertilizer and its time of application indicated that vegetative growth of cassava increased when mineral fertilizers were applied earlier than 12 weeks after planting. The results could be due to sufficient levels and ready availability of nitrogen, phosphorus and potassium in the mineral fertilizers which certainly supported vegetative growth. These observations support the report of [15] that, application of high level of nitrogen will lead to $11 \%$ increase in above-ground growth of cassava plants. The best response due to early application of mineral fertilizers may be attributed to early nutrient uptake and reduced nutrient losses by leaching, erosion, denitrification and volatilization.

\section{B. Treatment effects on root and total dry matter yields of cassava}

The poultry manure treatment outyielded the mineral fertilizer treatments in cassava root yield (Table 7). Results of the main effects of treatments showed that the highest fresh root, dry root and total dry matter yields of $23.34 \mathrm{t} / \mathrm{ha}, 8.50$ $\mathrm{t} / \mathrm{ha}$ and $17.43 \mathrm{t} / \mathrm{ha}$, respectively were obtained from poultry manure and this could be due to increased number of roots and root weight per plant measured in that treatment. This supports findings of [16] who reported that storage root number, storage root size and storage root girth were the principal yield components that increase cassava root yield. Poultry manure has other essential nutrients in addition to NPK and organic matter that are required for the growth of plants. [17] reported that addition of manure to the cassava plant increased nutritional elements in rooting zone, and this enhanced uptake of nutrients, resulting in the growth of the plant. Works of [18] showed that manure also increased availability of nutrients, especially N, P, K, Zn, Fe and Mn even from the early stages of crop growth. They further indicated that organic manure also improves the water holding capacity of the soil, soil structure, soil aeration and impact positively on growth, yield and root quality of cassava. These improved soil conditions could have enhanced assimilate partitioning in favour of root growth of cassava, culminating in high cassava root yield.

Application of poultry manure at 6 weeks after planting recorded the greatest interaction effect of $28.10 \mathrm{t} / \mathrm{ha}$ and 11.23 $\mathrm{t} / \mathrm{ha}$ for fresh root yield and dry root yield, respectively. The highest dry matter yield of $19.80 \mathrm{t} / \mathrm{ha}$ was obtained when poultry manure was applied at 12 weeks after planting (Table 7). Organic manures reduce leaching and nutrients embedded in them are expelled more steadily and slowly and are stored for a prolonged period of time in the soil, thereby ensuring a long residual effect [19]. This could have encouraged the formation of many and heavy roots per plant due to good vegetative growth which certainly translated into sufficient production and transfer of photosynthates. This means that early application of poultry manure could enhance its residual effects to improve both physical and chemical characteristics of the soil.

The average fresh root yield obtained was $22.02 \mathrm{t} / \mathrm{ha}$ and, this supports a report by [6] that yield of cassava increased from 12 to $25 \mathrm{t} /$ ha when moderate level of NPK was applied and when higher rates were applied yield increased more than $40 \mathrm{t} / \mathrm{ha}$. [7] observed that average fresh root yield increased from $13.7 \mathrm{t} / \mathrm{ha}$ without amendment to $23.7 \mathrm{t} / \mathrm{ha}$ with application of $4 \mathrm{t} / \mathrm{ha}$ of poultry manure. Yield figures 
recorded fell within the achievable yield range of 20 - $50 \mathrm{t} / \mathrm{ha}$ for the Bankyehemaa variety. The low amount of rainfall of $859.4 \mathrm{~mm}$ and poor edaphic conditions of the experimental site (Tables 1, 2 and 3) during growth period of the crop might have resulted in the inability of the crop to attain its highest yield. This corroborates findings of [20] who indicated that water stress during the early growth (1-5 months) has severe implications for root yield as this is the period for initiation of storage roots. In a similar study, [21] also reported that the responsiveness of cassava to fertilizers reduces if total rainfall falls below $1500 \mathrm{~mm}$.

[22] observed that potassium, the nutrient required in largest amounts by cassava for root formation, is liable to be low in highly weathered tropical soils. According to Howeler (1991), the critical levels of $\mathrm{pH}$ and nutrient set for cassava are $\mathrm{pH} 5.2-7.0,0.2 \% \mathrm{~N}, 7.3 \mathrm{mg} / \mathrm{kg}$ available $\mathrm{P}, 0.14-1.20$ $\mathrm{cmol} / \mathrm{kg}$ exchangeable $\mathrm{K}$, and 3-8 $\mathrm{cmol} / \mathrm{kg}$ exchangeable $\mathrm{Mg}$. Results of soil chemical analysis of the experimental site (Table 1) revealed that the content of nitrogen, potassium, phosphorus and magnesium were $0.07 \%, 0.00 \mathrm{cmol} / \mathrm{kg}, 7.80$ $\mathrm{pp}$ and $0.64 \mathrm{mg} / \mathrm{kg}$, respectively. These nutrient levels are far below the critical levels of nutrients required for large root yield of cassava.

\section{CONCLUSIONS}

- Fertilizer and its time of application did not generally affect vegetative growth, fresh root and dry matter yields of Bankyehemaa variety.

- There was significant interaction effect between fertilizer and its time of application on plant height, shoot weights, number of stems per plant, stem girth, root and total dry matter yields.

- $\quad$ Vegetative growth of Bankyehemaa increased when mineral fertilizers were applied earlier than 12 weeks after planting.

Application of poultry manure at 6 weeks after planting produced the highest fresh and dry root yields of cassava.

- The highest dry matter yield was obtained when poultry manure was applied at 12 weeks after planting.

\section{RECOMMENDATION}

- It is recommended that farmers should be encouraged to apply poultry manure at 6 weeks after planting to increase cassava root yield. Other forms of organic manures should also be tested on Bankyehemaa and other cassava varieties in different locations to evaluate varietal response to treatment modifications.

\section{ACKNOWLEDGEMENT}

Professor J. Sarkodie-Addo of the Department of Crop and Soil Sciences of the Faculty of Agriculture, KNUST, Kumasi, made this research successful and his good efforts are highly appreciated.

\section{REFERENCES}

[1] Nweke, F. I, Dixon, A. G. O, Asiedu, R, and Folayan, S. A. Collaborative Study of cassava in Africa. Cassava variety needs of farmers and potential for growth in Africa. COSCA Working Paper no. 10, 1994

[2] Allem, A. C. The origin and taxonomy of cassava, in Cassava: Biology, production and utilisation eds Hillocks R. J., Thresh J. M., Bellotti A. C., editors. New York, NY: CABI Publishing, pp. 1-16, 2002.

[3] Roa, A. C, Chavarriaga-Aguirre, P, Duque, M. C, Maya, M. M, Bonierbale, M. W, Iglesias, C, and Tohme, J. Cross-species amplification of cassava (Manihot esculenta) (Euphorbiaceae) microsatellites: allelic polymorphism and degree of relationship. American Journal of Botany, vol 87, no.11, pp.1647-1655, 2000.

[4] Allem, A. C. The origin of Manihot esculenta Crantz (Euphorbiaceae). Genetic Resources and Crop Evolution, vol. 41, pp. 133-150, 1994.

[5] FAO. The places of Agriculture in Sustainable Development: the way forward on SARD. Committee on Agriculture, Sixteenth Session, Item 7 of the provisional Agenda, Rome, pp. 26-30, 2000.

[6] Vanlauwe, B. Integrated Soil Fertility Management for Increased Productivity in Cassava-based Systems. Fact sheet prepared for FAO (mimeo), 2012.

[7] Adjei-Nsiah, S, and Issaka, R. N. Farmers' agronomic and social evaluation of evaluation of productivity, yield and cooking quality in four cassava varieties. American journal of experimental agriculture, vol. 3, pp. 165-174, 2013.

[8] Nweke, F. I. Cassava processing in sub-Saharan Africa: Implications for expanding cassava production. IITA Research, vol. 12, pp. 7-14, 1996.

[9] MoFA. Agriculture in Ghana: facts and figures. Produced by Statistics, Research, and Information Directorate: Crops Research Institute, Accra, Ghana. 2011.

[10] Quansah, C, Drechsel, P, and Lefroy, R. B. D. Peri-urban interface agricultural production systems. Soil fertility issues. In: Integrated Nutrient Management of Farmer's Fields-Approaches that work. Gregory, P.J. DFID/NRI/ University of Reading, U.K. Occasional Publications. no.1, pp. 199-200, 1997.

[11] GSS. Population and Housing Census, National Analytical Report, 2012.

[12] Payne, R.W, Murray, D. A, Harding, S. A, Baird, D. B, and Soutar, D. M. Genstat for Windows $\left(12^{\text {th }}\right.$ Edition) Introduction. VSN International, Hemel Hempstead, 2009.

[13] Boateng, B. A. Influence of rates and time of NPK fertilizer application on cassava (Manihot esculenta Crantz). Master of Philosophy (Agronomy) Thesis, School of Graduate Studies, Kwame Nkrumah University of Science and Technology (KNUST), Kumasi. pp.74, 2015.

[14] Howeler, R. H. Long term effects of cassava cultivation on soil productivity. Field Crops Research., vol. 26, no. 1, pp. 1-18, 1991.

[15] Krochmal, A, and Samuels, G. The Influence of NPK levels on the Growth and tuber Development of Cassava in Tanks. CEIBA, vol. 16, pp. 35-43, 1970.

[16] Ntawuruhunga, P, and Dixon, A. Quantitative variation and interrelationship between factors influencing cassava yield. Journal of Applied Biosciences, vol 26, pp. 1594-1602, 2010.

[17] Shafeek, M. R, Nadia, N, Omar, M, Mahmad, R. A, and Abd El-Baky, M. M. Effect of Bio- organic fertilization on growth and yield of cassava plants in newly cultivated land. Vegetables Dept., National Res. Center, Dokki, Cairo, Egypt, 2012.

[18] Ayoola, O. T, and Makinde, E. A. Complementary organic and inorganic fertilizer application: influence on growth and yield of cassava/maize/melon intercrop with a relayed cowpea. Australian Journal of Basic and Applied Sciences, vol. 1, no. 3, pp. 187-192, 2007.

[19] Tisdale, S. L, Nelson, W. J, and Beaton, J. D. Soil Fertility and Fertlizers. Macmillan Publishing Company. $4^{\text {th }}$ Edition.New York Tolessa, D. and Friensen, D.K. (2001). Effect of enriching farmyard manure with mineral fertilizer on grain yield of Maize at Bako, Western Ethiopia.Seventh Eastern and Southern Africa Regional Maize Conference. $11^{\text {th }}-15^{\text {th }}$ February. pp. 335-337, 1993.

[20] Duque, L, Setter, T, Ceballos, H, Fregene, M, and Alves, A. Evaluation of drought tolerance in contrasting cassava varieties genotypes under field controlled water stressed environment. Paper presented at the first scientific meeting of the Global Cassava Partnership CGP-1, Ghent, 21-25 July, 2008.

[21] Anneke, M, Fermont, P, Tittonell, A, Yona, B, Ntawuruhunga, P, and Giller, K. E. Towards understanding factors that govern fertilizer response in cassava: Lessons from East Africa, 2009. DOI 10.1007/s10705-009-9278-3.

[22] Howeler, R. H. Response of cassava to VAM mychorizal inoculation. Plant and Soil Science, vol. 69, pp. 327-339, 1980. 